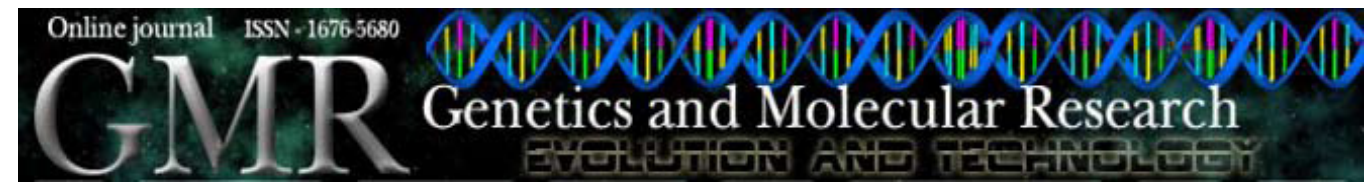

\title{
Genetic characterization of natural populations of the medicinal plant Palicourea coriacea (Rubiaceae) with molecular markers
}

\author{
T.C.S. Barbosa ${ }^{1}$, S.T. Sibov², M.P.C. Telles ${ }^{2}$ and T.N. Soares ${ }^{2}$ \\ ${ }^{1}$ Instituto do Trópico Subúmido, Universidade Católica de Goiás, \\ Campus II, Goiânia, GO, Brasil \\ ${ }^{2}$ Departamento de Biologia Geral, \\ Instituto de Ciências Biológicas, Universidade Federal de Goiás, \\ Campus II, Goiânia, GO, Brasil \\ Corresponding author: S.T. Sibov \\ E-mail: stsibov@yahoo.com.br
}

Genet. Mol. Res. 9 (2): 695-704 (2010)

Received August 10, 2009

Accepted January 28, 2010

Published April 20, 2010

DOI 10.4238/vol9-2gmr671

\begin{abstract}
Palicourea coriacea (Rubiaceae) is a herbaceous, perennial species typical of the Cerrado; it is popularly known as "douradinha", because of its yellow flowers. It is utilized in popular medicine, mainly for the treatment of renal diseases. We used RAPD markers to evaluate the genetic structure of nine natural populations of $P$. coriacea, totaling 168 individuals, collected in the States of Goiás and Bahia. This species showed a high level of genetic diversity, with He values varying between 0.259 and 0.338 , with an overall mean of 0.296 . Analysis by AMOVA revealed that $23 \%$ of the total variability was between populations and $77 \%$ was within populations. The estimate of apparent gene flow $(\mathrm{Nm})$ was 0.83 . Analyses of the fixation index $(f)$ using a Bayesian approach yielded a mean value of 0.98 , suggesting that this is an autogamous species. Analyses of genetic divergence and spatial pattern of the populations utilizing $\theta^{\mathrm{B}}$ and $\Phi_{\mathrm{ST}}$ matrices, pair to pair, revealed no correlation between geographic distance and genetic distance; the nine populations grouped randomly, without relation to their geographic origin. The hypothesis that geographically close populations should be genetically
\end{abstract}


close was discarded based on the Mantel test; the correlation was 0.155 $(\mathrm{P}=0.23)$. The degree of interpopulational differentiation was relatively high, which allows us to recommend a strategy of sampling for the ex situ conservation of genetic variability, utilizing a larger number of populations. For in situ conservation, we suggest preservation of a larger number of areas in the Cerrado, where this species naturally occurs.

Key words: Douradinha; Random amplified polymorphic DNA; Genetic variability

\section{INTRODUCTION}

The conservation of genetic resources of tropical biomes is one of the most preeminent topics nowadays. The conservation and management of biodiversity, even in protected areas in the tropics, are complex challenges that require a basic understanding of the distribution and abundance of species, their mutualistic interactions, their reproductive biology, and the genetic structure of their populations (Mittermeier et al., 1992).

Besides being a species much utilized in popular medicine (Laureano, 2001), Palicourea coriacea (Cham.) K. Schum (Rubiaceae) occurs in a highly threatened ecosystem such as the Cerrado, due to the great expansion of agricultural lands, where only $20 \%$ of its original vegetation is preserved (Myers et al., 2000; Marris, 2005). These facts reinforce the necessity of studies for its conservation in particular and of the biome as a whole.

According to Yunes and Filho (2001), approximately $25 \%$ of the drugs employed in industrialized countries come directly or indirectly from natural products. Considering the richness of species existing in the Cerrado and their uses, emphasis can be given to those species that are purportedly medicinal and that may offer therapeutic resources. $P$. coriacea is a herbaceous species measuring up to $80 \mathrm{~cm}$ in height and frequently forms bushes. It is a perennial deciduous plant, with a seasonal aerial biomass; from July to October, there is no green mass, where in this period only a yellow stem is observed. Sprouting resurges in the rainy period, in November, with the first leaves emerging close to the ground in a cespitose manner. Flowering begins in the month of November, continuing until March. The inflorescences are terminal with white flowers and well-developed bracts colored yellow. The fruits, drupes, are blue and are found starting in April (Laureano, 2001).

Native species such as $P$. coriacea, utilized indiscriminately by populations residing in the regions of the Cerrado, are scientifically known by their genetic variability as well as proven therapeutic properties.

Therefore, the aim of the present study was to characterize the genetics of the species P. coriacea utilizing random amplified polymorphic DNA (RAPD) molecular markers (Williams et al., 1990), focusing on their genetic variability, population structure and gene flow.

\section{MATERIAL AND METHODS}

In this study, 20 to 30 individuals from nine populations of the species P. coriacea were collected from locations in the States of Goiás and Bahia, totaling 251 individuals. The collection sites were determined based on interviews with locals of the region and after pros- 
pecting trips. Each population collected was identified by its geographic coordinates and altitude determined with help of GPS (Table 1, Figure 1).

\begin{tabular}{|c|c|c|c|c|}
\hline Population & Municipality & Latitude (S) & Longitude $(\mathrm{W})$ & Altitude (m) \\
\hline $1-\mathrm{ABA}$ & Abadia de Goiás (GO) & $16^{\circ} 41^{\prime} 26^{\prime \prime}$ & $49^{\circ} 15^{\prime}$ & 898 \\
\hline 2 - URU & Uruaçu (GO) & $14^{\circ} 31^{\prime} 24^{\prime \prime}$ & $49^{\circ} 09^{\prime}$ & 520 \\
\hline 3 - CRI & Cristianópolis (GO) & $17^{\circ} 12^{\prime} 00^{\prime \prime}$ & $48^{\circ} 42^{\prime}$ & 802 \\
\hline 4 - COR1 & Correntina 1 (BA) & $13^{\circ} 26^{\prime} 00^{\prime \prime}$ & $45^{\circ} 18^{\prime}$ & 680 \\
\hline $5-\mathrm{COR} 2$ & Correntina 2 (BA) & $13^{\circ} 33^{\prime} 57^{\prime \prime}$ & $45^{\circ} 29^{\prime}$ & 680 \\
\hline 6 - JAT & Jatai (GO) & $17^{\circ} 51^{\prime} 50 \prime$ & $52^{\circ} 00^{\prime}$ & 702 \\
\hline 7 - GUA & Guapó (GO) & $16^{\circ} 50^{\prime} 53^{\prime \prime}$ & $49^{\circ} 33^{\prime}$ & 707 \\
\hline 8 - PER & Perolândia (GO) & $17^{\circ} 36^{\prime} 43^{\prime \prime}$ & $52^{\circ} 02^{\prime}$ & 889 \\
\hline $9-\mathrm{CAI}$ & Caiapônia (GO) & $17^{\circ} 19^{\prime} 29^{\prime \prime}$ & $51^{\circ} 47^{\prime}$ & 752 \\
\hline
\end{tabular}

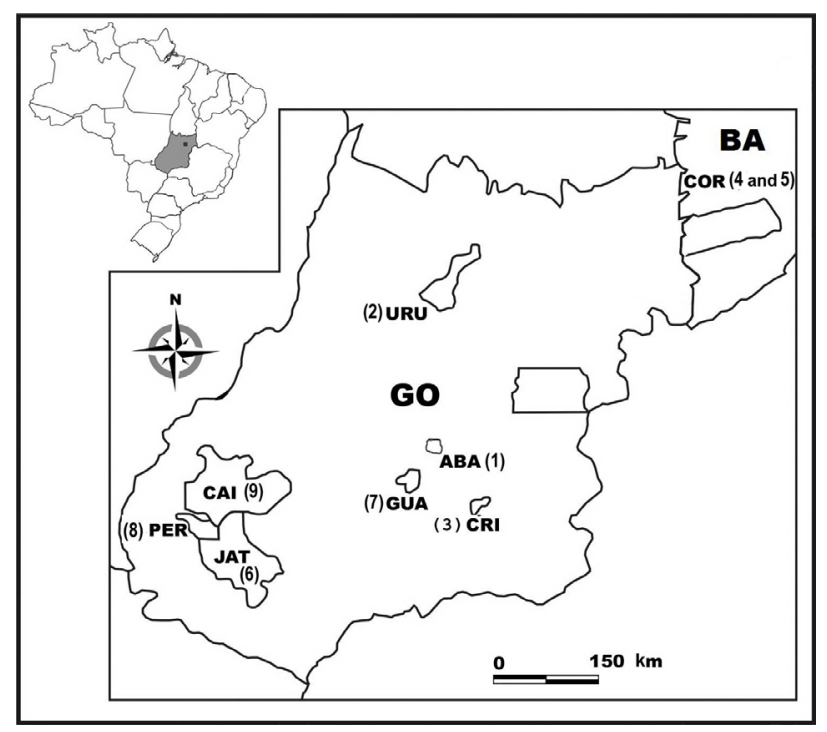

Figure 1. Map of the State of Goiás (GO) and part of Bahia (BA) with the collection areas for 9 natural populations of Palicourea coriacea. ABA (Abadia de Goiás), COR (Correntina), CRI (Cristianópolis), GUA (Guapó), CAI (Caiapônia), PER (Perolândia), JAT (Jatai), URU (Uruaçu).

The areas where the collections were carried out (western part of Bahia State and Goiás State) fit in the climatic region Aw of the Köppen climate classification (IBGE, 2000). The climate type Aw characterizes a region with a rainy and dry season, showing small variations from east to west.

The material collected consisted of six to eight young, healthy leaves of each individual, which were placed in 50-mL plastic tubes and kept in ice while transported to the Laboratory of Molecular Biology of Plants (LBMP), Sector of Plant Breeding, School of Agronomy and Food Engineering of UFG, where they were stored in a freezer at $-20^{\circ} \mathrm{C}$ until the time of DNA extraction.

DNA was extracted according to the $2 \%$ CTAB protocol described by Ferreira and Grattapaglia (1998). Once isolated, DNA was dried, resuspended in $50 \mu \mathrm{L}$ TE buffer $(10 \mathrm{mM}$ Tris-HCl, $\mathrm{pH} 8.0,0.1 \mathrm{mM}$ EDTA) and stored in a freezer at $-20^{\circ} \mathrm{C}$. 
Amplification reactions were optimized at LBMP/UFG and carried out using $10 \mathrm{ng} / \mu \mathrm{L}$ genomic DNA in a final volume of $15 \mu \mathrm{L}$, containing the following reagents: $50 \mathrm{mM} \mathrm{KCl}, 20 \mathrm{mM}$ Tris-HCl, $\mathrm{pH} 8.8,2.8 \mathrm{mM} \mathrm{MgCl}, 0.4 \mathrm{mM}$ dNTPs, $2 \mu \mathrm{M}$ primer and $1 \mathrm{U}$ Taq DNA polymerase. Polymerase chain reaction was performed utilizing the thermocycler model PTC - 100 (MJ Research, Watertown, USA), programmed for an initial denaturation step at $94^{\circ} \mathrm{C}$ for $5 \mathrm{~min}$ and 49 cycles at $92^{\circ} \mathrm{C}$ for $30 \mathrm{~s}, 37^{\circ} \mathrm{C}$ for $1 \mathrm{~min}$ and $30 \mathrm{~s}$ and $72^{\circ} \mathrm{C}$ for $1 \mathrm{~min}$ and $30 \mathrm{~s}$, ending with an additional extension step at $72^{\circ} \mathrm{C}$ for $6 \mathrm{~min}$. The amplification reaction products were separated by $1.2 \%$ agarose gel horizontal electrophoresis at $90 \mathrm{~V}$ for $4 \mathrm{~h}$. The gels were stained with ethidium bromide, and amplification products were visualized and photographed under UV light.

The primers (Operon Technologies, Inc.; Alameda, CA, USA) were surveyed in sideby-side duplicate reactions for three individuals of $P$. coriacea, to identify primers that yielded a reproducible and scorable banding pattern. In a second step, primers with consistent and well-amplified bands were used to analyze the full set of DNA samples.

Based on the genotyping from the gels, a matrix was generated with binary data, presence (1) and absence (2) of RAPD bands. This matrix was used to calculate genetic diversity, with the help of the POPGENE version 1.32 program (Population Genetic Analysis) (Yeh and Boyle, 1997). Based on the population allelic frequencies obtained by the method of Lynch and Milligan (1994), estimates were made of the genetic diversity indices per population data for Nei's (1972) expected heterozygosity, and the percentage of polymorphic loci in the populations.

Next, we carried out structuration analyses of genetic variability based on classical statistics, with the analysis of molecular variance (AMOVA) (Excoffier et al., 1992), for which the Arlequin version 2.0 software (Schneider et al., 2000) was utilized and based on Bayesian statistics proposed by Holsinger et al. (2002) using the HICKORY version 1.0 program (Holsinger and Lewis, 2003). In this program, the value of genetic structuration between populations is given by the $\theta^{B}$ index, which is calculated by means of four different models, full model, $\theta^{\mathrm{B}}$, free $f$, and $f=0$. The selection of the best model is carried out utilizing the various parameters, $\mathrm{I}, \mathrm{H}-\mathrm{d}$, DIC, and Dbar.

From the analyses of population genetic structure, the number of migrants per generation $(\mathrm{Nm})$ was calculated based on the expression: $N m=(1 / 4)\left[\left(1 / \mathrm{F}_{\mathrm{ST}}\right)-1\right]$ (Wright, 1951), in which $\mathrm{F}_{\mathrm{ST}}$ is substituted by $\Phi_{\mathrm{ST}}$ and $\theta^{\mathrm{B}}$ (Telles et al., 2006; Soares et al., 2008).

Population genetic divergence was determined by calculating the $\theta^{\mathrm{B}}$ index between pairs of populations, utilizing the HICKORY version 1.0 program. The genetic distance matrix was utilized for the graphic representation of the genetic divergence pattern among the populations. Grouping analysis was performed based on the UPGMA (unweighted pair-group method by arithmetic mean) criterion, which produces a hierarchical arrangement of classification of the populations, represented by a dendrogram. For the purpose of testing the significance of the association between the genetic distance and geographic distance matrices, the Mantel test statistic Z was utilized with 1000 permutations (Manly, 1997). The grouping analyses and the Mantel test were performed in the NTSYS 1.5 package (Numerical Taxonomy and Multivariate Analyses System) (Rohlf, 1998).

\section{RESULTS}

P. coriacea occurs in greater abundance in the Biogeographic System of the Cerrados. Preliminary data indicated that the occurrence of this species would be restricted to the subsystem of Campo Sujo. However, according to the information obtained during the prospecting 
phase and plant material collection, it could be noted that its distribution was not uniform or associated with a specific environment as previously described. The species occurs in areas of Chapadões, Covais, areas of the Cerrado sensu strict, and up to the Cerradão (Table 2).

Table 2. Physionomic type and characterization of the environment and soil of the locations where 9 populations
of Palicourea coriacea were collected.
\begin{tabular}{llll}
\hline Population & Physionomic type & Conservation of environment & \multicolumn{1}{c}{ Characterization of soil } \\
\hline 1 - ABA & sensu stricto & Anthropized & Gneisses, amphibolite, shale, kyanite, and calcite \\
2 - URU & sensu stricto & Anthropized & Gabbro, pyroxenites, amphibolites, and metabasites \\
3 - CRI & sensu stricto & Intact & Gneisses, amphibolite, shale, kyanite, and calcite \\
4- COR1 & Cerradão & Intact & Areno-clayey \\
5 - COR2 & Campina & Intact & Areno-clayey \\
6 - JAT & Covais & Intact & Clay-sandy \\
7 - GUA & sensu stricto & Anthropized & Gneisses, amphibolite, shale, kyanite, and calcite \\
8- PER & Cerradão & Intact & Basaltic rocks \\
9 - CAI & sensu stricto & Intact & Silty and clayey \\
\hline
\end{tabular}

Among the 94 RAPD primers of the Operon Technologies series tested for the species $P$. coriacea, 10 were selected (Table 3 ) that showed the best amplification profiles and the highest numbers of loci per primer, varying from 12 (OPAA-07) to 20 (OPH-11) and totaling 164 loci. The size of the amplified fragments varied from 123 to $1722 \mathrm{bp}$.

Table 3. RAPD primers selected for the species Palicourea coriacea with their base sequences, number of loci amplified and variation range of loci.

\begin{tabular}{llcr}
\hline Primer & Sequence 5' $\rightarrow 3^{\prime}$ & No. of loci & Range (bp) \\
\hline OPAA-07 & CTA CGC TCA C & 12 & 246 to 1599 \\
OBP-08 & GTC CAC ACG G & 17 & 246 to 1599 \\
OBP-11 & GTA GAC CCG T & 15 & 246 to 1476 \\
OBP-12 & CCT TGA CGC A & 14 & 123 to 1353 \\
OBP-13 & TTC CCC CGC T & 16 & 246 to 1722 \\
OPF-06 & GGG AAT TCG G & 19 & 123 to 1722 \\
OPG-17 & ACG ACC GAC A & 18 & 123 to 1599 \\
OPH-03 & AGA CGT CCA C & 15 & 123 to 1476 \\
OPH-11 & CTT CCG CAG T & 20 & 246 to 1722 \\
OPAC-14 & GTC GGT TGT C & 18 & 123 to 1476 \\
Total & & 164 & \\
\hline
\end{tabular}

Although 251 individuals had been collected, for a more concise analysis of the data, individuals with more than $30 \%$ of data lost were omitted, totaling 168 individuals with a mean of 18.66 individuals per population (Table 4). The mean number of loci was 16.4 per primer, and there was no evidence of monomorphic loci in any of the populations.

Table 4. Relation of sample size (N), Nei's heterozygosity (He), Shannon's $(H)$, number of polymorphic loci (PL), and percentage of polymorphic loci per population of Palicourea coriacea.

\begin{tabular}{|c|c|c|c|c|c|}
\hline Population & $\mathrm{N}$ & $\mathrm{He}$ & $H$ & PL & Polymorphic loci (\%) \\
\hline $1-\mathrm{ABA}$ & 28 & 0.338 & 0.507 & 157 & $95.73 \%$ \\
\hline 2 - URU & 13 & 0.259 & 0.396 & 136 & $82.93 \%$ \\
\hline 3 - CRI & 9 & 0.304 & 0.461 & 149 & $90.85 \%$ \\
\hline $4-\mathrm{COR} 1$ & 26 & 0.297 & 0.450 & 149 & $90.85 \%$ \\
\hline $5-\mathrm{COR} 2$ & 18 & 0.259 & 0.402 & 144 & $87.80 \%$ \\
\hline 6 - JAT & 21 & 0.296 & 0.451 & 152 & $92.68 \%$ \\
\hline 7 - GUA & 25 & 0.312 & 0.469 & 151 & $92.07 \%$ \\
\hline 8 - PER & 14 & 0.319 & 0.479 & 149 & $90.85 \%$ \\
\hline 9 - CAI & 14 & 0.284 & 0.435 & 147 & $89.63 \%$ \\
\hline Total & 168 & 0.296 & 0.565 & 164 & $100.00 \%$ \\
\hline
\end{tabular}


The percentage of polymorphic loci observed in each population, varied from $82.93 \%$ (Uruaçu) to $95.73 \%$ (Abadia de Goiás). Genetic diversity or Nei's (1972) expected heterozygosity was high and varied between 0.259 and 0.338 in the populations, with a general value of 0.296 (Table 4).

AMOVA yielded a $\Phi_{\mathrm{ST}}$ value of 0.230 , utilizing 1000 permutations, indicating that $23 \%$ of genetic variability is found among populations and $77 \%$ of genetic variability is within populations (Table 5), while the $\Phi_{\mathrm{ST}}$ value for the pairs of populations varied between 0.109 and 0.235 (Figure 2).

The estimates utilizing Bayesian statistics also yielded a value similar to that obtained by AMOVA, with a $\theta^{\mathrm{B}}$ value of 0.22 (Tables 6 and 7), indicating that $22 \%$ of genetic variability is found among populations.

\begin{tabular}{l|ccccccccc}
\multicolumn{1}{c}{} & 1 & 2 & 3 & 4 & 5 & 6 & 7 & 8 & 9 \\
\cline { 2 - 11 } & 0.000 & & & & & & & & \\
2 & 0.179 & 0.000 & & & & & & & \\
3 & 0.121 & 0.142 & 0.000 & & & & & & \\
4 & 0.190 & 0.193 & 0.169 & 0.000 & & & & & \\
5 & 0.150 & 0.183 & 0.141 & 0.174 & 0.000 & & & & \\
6 & 0.174 & 0.188 & 0.158 & 0.187 & 0.165 & 0.000 & & & \\
7 & 0.188 & 0.235 & 0.175 & 0.215 & 0.212 & 0.179 & 0.000 & & \\
8 & 0.160 & 0.186 & 0.141 & 0.179 & 0.165 & 0.143 & 0.176 & 0.000 & \\
9 & 0.169 & 0.143 & 0.131 & 0.168 & 0.150 & 0.143 & 0.183 & 0.109 & 0.000
\end{tabular}

Figure 2. Matrix of genetic distance based on pairwise $\Phi_{\mathrm{ST}}$ values between 9 populations of Palicourea coriacea, with regard to 164 RAPD loci.

Table 5. Analysis of molecular variance (AMOVA) and estimate of gene flow $(\mathrm{Nm})$ calculated by the Wright method (1951) based on 164 RAPD loci.

\begin{tabular}{lrcccc}
\hline SV & d.f. & SS & \%Total variation & E(MS) & $\Phi_{\text {ST }}$ \\
\hline Between & 8 & 1401.52 & 23.01 & $8.06 \mathrm{Va}$ & 0.23 \\
Within & 159 & 4285.83 & 76.99 & $26.95 \mathrm{Vb}$ & $0.77(1-\Phi)$ \\
Total & 167 & 5687.35 & 35.01 & &
\end{tabular}

$\mathrm{SV}=$ source of variation; d.f. $=$ degrees of freedom; $\mathrm{SS}=$ sum of squares; $\%$ Total variance $=$ genetic diversity attributable to differences among individuals in different hierarchical levels; $\mathrm{E}(\mathrm{MS})=$ expected mean squares; $\Phi_{\mathrm{ST}}=(\mathrm{PhyST})=$ proportion of the molecular variability of haplotypes between populations; $N_{m}=$ number of migrants per generation.

\begin{tabular}{|c|c|c|c|c|}
\hline Model & $F$ & $\theta^{\mathrm{B}}$ & Dbar & DIC \\
\hline Full & 0.98 & 0.22 & 5481.60 & 6541.79 \\
\hline$f=0$ & - & 0.16 & 5488.90 & 6593.16 \\
\hline$\theta^{\mathrm{B}}=0$ & 0.96 & - & $11,437.11$ & $11,598.45$ \\
\hline Free $f$ & 0.50 & 0.20 & 5582.98 & 6707.82 \\
\hline
\end{tabular}

Table 7. Bayesian analysis among 9 populations of Palicourea coriacea, including measures of information $\mathrm{I}_{e}$ and $\mathrm{H}-\mathrm{d}$ distances between the $a$ posteriori distribution and a $\beta$ distribution, for the four models tested.

\begin{tabular}{|c|c|c|c|c|c|c|c|c|}
\hline \multirow[t]{2}{*}{ Model } & \multicolumn{2}{|c|}{ Full } & \multicolumn{2}{|c|}{$f=0$} & \multicolumn{2}{|c|}{$\theta^{\mathrm{B}}=0$} & \multicolumn{2}{|c|}{ Free $f$} \\
\hline & $\mathrm{I}_{\mathrm{e}}$ & H-d & $\mathrm{I}_{\mathrm{e}}$ & H-d & $\mathrm{I}_{\mathrm{e}}$ & H-d & $\mathrm{I}_{\mathrm{e}}$ & $\mathrm{H}-\mathrm{d}$ \\
\hline $\begin{array}{l}F \\
\theta^{\mathrm{B}}\end{array}$ & $\begin{array}{l}3.0383 \\
3.4188\end{array}$ & $\begin{array}{l}0.0024 \\
0.0007\end{array}$ & $\begin{array}{c}- \\
3.6658\end{array}$ & $\begin{array}{c}- \\
0.0007\end{array}$ & $\begin{array}{c}2.1382 \\
-\end{array}$ & $\begin{array}{c}0.0030 \\
-\end{array}$ & $\begin{array}{l}0.0001 \\
2.8076\end{array}$ & $\begin{array}{l}0.0020 \\
0.0095\end{array}$ \\
\hline
\end{tabular}


Based on the full model, the model chosen to represent the estimate of genetic variability between and within the populations of $P$. coriacea, the $f$ value was 0.98 , where this index is the same as Wright's $F_{\text {IS }}$ and suggests that this species behaves as a preferentially autogamous species. However, this indication is made with caution, because dominant markers, such as RAPD, are not the most suitable for making inferences regarding the reproductive system.

$P$. coriacea did not show great phenotypic differences between the populations analyzed. However, variations such as the shape of leaves, flowers and fruits occur and they deserve specific study regarding characterization and phenology. Climatic differences also did not exist. All the region of the populations analyzed is an Aw climatic region of the Köppen system.

On analyzing the dendrogram obtained (Figure 3), no clear relationship can be seen between genetic and geographic distances. Populations geographically close, such as Abadia de Goiás (1) and Guapó (7), are genetically distant from each other. Besides this, it was demonstrated that the groupings obtained utilizing the distance matrices $\Phi_{\mathrm{ST}}$ and $\theta^{\mathrm{B}}$ showed no differences between the two statistics.

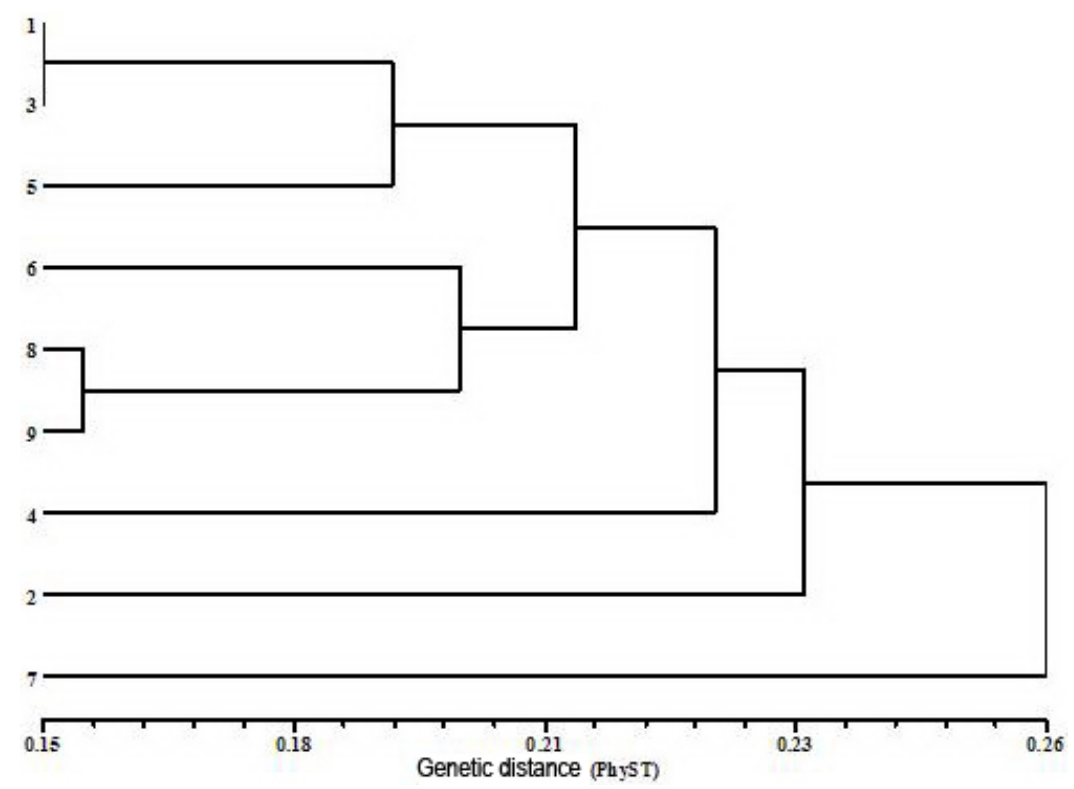

Figure 3. Dendrogram generated from the UPGMA criterion presenting the pairwise $\Phi_{\mathrm{ST}}$ genetic distances for the 9 populations of Palicourea coriacea based on 164 RAPD loci. Cophenetic correlation equal to 0.826. $1=$ Abadia de Goiás; $2=$ Uruaçu; $3=$ Cristianópolis; $4=$ Correntina 1; $5=$ Correntina 2; $6=$ Jatai; $7=$ Guapó; $8=$ Perolândia; $9=$ Caiapônia. $\Phi_{\mathrm{ST}}(\mathrm{PhyST})=$ proportion of the molecular variability of haplotypes between populations.

The Mantel test showed a low matrix correlation between genetic distance and geographic distance equal to 0.155 , which was not significant ( $\mathrm{P}=0.239$ with 1000 permutations). These results demonstrate that there is no clear spatial pattern that make it possible to derive a global interpretation of structuration of genetic variability from the geographic distances. That is, it is not possible to observe the formation of groups among the sample of populations that are geographically close, suggesting that these are evolving independently one from the other. These results confirm what was observed in the dendrogram. 


\section{DISCUSSION}

The results obtained with RAPD in this study as with those with other native species, such as baru (Dipteryx alata), araticum (Annona crassiflora), mangaba (Hancornia speciosa Gomez), and cagaita (Eugenia dysenterica), utilizing RAPD markers, demonstrated that there is a large number of polymorphic loci in the populations studied and that these populations showed a high genetic diversity (Telles et al., 2001, 2003; Moura, 2003; Trindade and Chaves, 2005; Zucchi et al., 2005; Soares, et al., 2008). This high level of genetic diversity was also found in the populations of $P$. coriacea, allowing the adaptation of these possible environmental changes and the maintenance of their evolutionary potential. This information is important, because low levels of diversity can cause serious effects on the population such as deleterious effects on the adaptation and persistence of these populations (Reed and Frankham, 2003).

The degree of structuration of the genetic variability observed in the populations of $P$. coriacea is considered to be high and is compatible with the values normally found for some native plants of the Cerrado. For example, Araújo (2001) and Zucchi et al. (2005) found values of $\sigma_{\Sigma \mathrm{T}}$ equal to 0.26 (Caryocar brasiliense) and 0.27 (Eugenia dysenterica DC.), respectively. For the species $D$. alata, the values found for both $\theta^{\mathrm{B}}$ and $\Phi_{\mathrm{ST}}$ were lower than those found in the present study, showing about 0.15 genetic structuration among the populations (Soares et al., 2008). It is important to point out that these species show a habit and reproductive biology that are generally very different compared to $P$. coriacea, but the lack of population genetic studies for plants of the Cerrado make it difficult to establish comparison with species more biologically close. It is also difficult to compare studies using the same molecular tools.

Knowledge of the distribution of genetic diversity between and within natural populations is essential for establishing programs for germplasm conservation and management under in situ and ex situ conditions (Vencovsky et al., 2007). With respect to the ex situ conservation of $P$. coriacea, it would be necessary to collect a large number of populations, because, according to what was observed with the $\Phi_{\mathrm{ST}}$ and $\theta^{\mathrm{B}}$ values, the populations possess great genetic differences among them. Each population has different alleles, and by collecting individuals from a greater number of populations, a larger sampling of the genome of this species would be achieved.

From an in situ conservation point of view, it would be necessary to establish conservation strategies of the areas where there are still populations of P. coriacea. Greater importance should be given to the fact that this species has medicinal value. Thus, the active principles of these species can be related to the environment or location where these populations were collected. Based on the genetic structure values obtained and from the simplified expression of Vencovsky and Crossa (1999), for the species $P$. coriacea, it would be necessary to have a conservation of at least 230 populations, to obtain an ideal $N_{e}$, equal to 500 . From a point of view of in situ conservation, this again shows the importance of the conservation of spots of the Cerrado in private properties besides that of already existing legal reserves.

What can also be observed in this study is that despite some populations having been collected in the same environment of the Cerrado, they did not show the same morphologic characteristics, such as large broad leaves or small or long leaves. This suggests that this morphologic divergence observed may not be attributed solely to environmental variations such as climate and soil type, but possibly to a genetic variation due to the high degree of genetic structuration observed in the populations. However, to test this hypothesis, it would be neces- 
sary to collect the morphologic data with more criteria and include them in the evaluation of the distribution of variability.

The apparent gene flow found for the populations of $P$. coriacea was 0.83 , which is considered low, and according to Slatkin (1987), the resultant genetics will lead to population differentiation if the flow value is less than one migrant per generation. Studies on the rates of gene flow in species with different pollination syndromes revealed that for species that are predominantly self-pollinating, mean gene flow was 0.83 as found for $P$. coriacea; for species pollinated by animals, mean gene flow was 1.21 , while in species pollinated by wind, mean gene flow was 2.91 (Govindaraju, 1988). Thus, the value found offers indications of the possible reproductive system of $P$. coriacea.

Despite the high degree of population genetic structure found and, consequently, the low gene flow, no spatial pattern of genetic variability was found in the populations of $P$. coriacea, evidenced by the non-significant value with the Mantel test. Thus, the most likely model of gene flow for these populations of $P$. coriacea, is the island model, in which migration occurs by chance within a group of populations, not leading to structuration of genetic variability in geographic space (Slatkin, 1987).

\section{CONCLUSIONS}

The species $P$. coriacea shows a high level of genetic diversity, indicating a high genetic variability in the populations, and thus, this species is strongly structured, with a value of $\Phi_{\mathrm{ST}}=0.23\left(\theta^{\mathrm{B}}=0.22\right)$.

The Mantel test reveals that there is no correlation between the genetic and geographic distances; that is, genetic variability demonstrates that these populations are not structured in space.

The low number of migrants per generation $(\mathrm{Nm}=0.83)$, the high genetic structuration of the populations, and principally the value of the fixation index $(f=0.98)$ estimated by Bayesian statistics suggest that the species is preferentially autogamous.

\section{ACKNOWLEDGMENTS}

We thank the Post-Graduation Program in Agronomy of the Universidade Federal de Goiás for supporting this study, the team of the Instituto do Trópico Subúmido (ITS) of the Universidade Católica de Goiás for their support during the whole course of this study, especially in the collection of plant material, and the team of the Genetics and Biodiversity Laboratory of the Universidade Federal de Goiás for their support in the analyses of the data.

\section{REFERENCES}

Araújo TCC (2001). Estrutura da Variabilidade Genética e Estrutura Populacional de Caryocar brasiliense Camb. no Estado de Goiás Utilizando Marcadores RAPD. Master's thesis, Instituto de Ciências Biológicas, Universidade Federal de Goiás, Goiânia.

Excoffier L, Smouse PE and Quattro JM (1992). Analysis of molecular variance inferred from metric distances among DNA haplotypes: application to human mitochondrial DNA restriction data. Genetics 131: 479-491.

Ferreira ME and Grattapaglia D (1998). Introdução ao Uso de Marcadores Moleculares em Análise Genética. EMBRAPA - CENARGEN, Brasília.

Govindaraju DR (1988). Variation in gene flow levels among predominantly self-pollinated plants. J. Evol. Biol. 2: $173-181$. Holsinger KE and Lewis PO (2003). HICKORY v. 1.0. Department of Ecology and Evolutionary Biology, University of 
Connecticut, Storrs. Available at [http://www.ceb.unconn.edu/]. Accessed December 5, 2005.

Holsinger KE, Lewis PO and Dey DK (2002). A Bayesian approach to inferring population structure from dominant markers. Mol. Ecol. 11: 1157-1164.

Instituto Brasileiro de Geografia Estatística (IBGE) (2000). Atlas Nacional do Brasil. IBGE, Rio de Janeiro.

Laureano LC (2001). Morfoanatomia, Perfil Fitoquímico e Aspectos Etnobotânicos das Espécies Medicinais do Cerrado: Palicourea coriacea (Cham.) Schum. e Rudgea viburnoides (Cham.) Benth. (Rubiaceae). Master's thesis, Instituto de Ciências Biológicas, Universidade Federal de Goiás, Goiânia.

Lynch M and Milligan BG (1994). Analysis of population genetic structure with RAPD markers. Mol. Ecol. 3: 91-99.

Manly BFJ (1997). Randomization, Bootstrap and Monte Carlo Methods in Biology. Chapman \& Hall, London.

Marris E (2005). Conservation in Brazil: the forgotten ecosystem. Nature 437: 944-945.

Mittermeier RA, Ayres JM, Werner T and Fonseca GB (1992). O país da megadiversidade. Cienc. Hoje 14: 20-27.

Moura NF (2003). Estrutura Genética de Subpopulações de Mangabeira (Hancornia speciosa Gomez) nos Cerrados do Brasil Central. Master's thesis, Escola de Agronomia e Engenharia de Alimentos, Universidade Federal de Goiás, Goiânia.

Myers N, Mittermeier RA, Mittermeier CG, da Fonseca GA, et al. (2000). Biodiversity hotspots for conservation priorities. Nature 403: 853-858.

Nei M (1972). Genetic distance between populations. Am. Nat. 106: 283-292.

Reed DH and Frankham R (2003). Correlation between fitness and genetic diversity. Conserv. Biol. 17: 230-237.

Rohlf FJ (1998). NTSYS-Pc: Numerical Taxonomy and Multivariate Analysis System (Software). Exeter Publishers, New York.

Schneider S, Roessli D and Excoffier L (2000). Arlequin Version 2000: A Software for Population Genetic Data Analysis. Genetics and Biometry Laboratory, University of Geneva, Geneva. Available at [http://anthro.unige.ch/arlequin]. Accessed June 5, 2005.

Slatkin M (1987). Gene flow and the geographic structure of natural populations. Science 236: 787-792.

Soares TN, Chaves LJ, de Campos Telles MP, Diniz-Filho JA, et al. (2008). Landscape conservation genetics of Dipteryx alata ("baru" tree: Fabaceae) from Cerrado region of central Brazil. Genetica 132: 9-19.

Telles MPC, Silva RSM, Chaves LJ, Coelho ASG, et al. (2001). Divergence among local populations of Eugenia dysenterica in response to edaphic patterns and spatial distribution. Pesq. Agropec. Bras. 36: 1387-1394.

Telles MPC, Valva FD, Bandeira LF and Coelho ASG (2003). Genetic characterization of natural populations of "araticunzeiro" (Annona crassiflora Mart. - Annonaceae) collected in the State of Goiás, Brazil. Rev. Bras. Bot. 26: 123-129.

Telles MP, Bastos RP, Soares TN, Resende LV, et al. (2006). RAPD variation and population genetic structure of Physalaemus cuvieri (Anura: Leptodactylidae) in Central Brazil. Genetica 128: 323-332.

Trindade MG and Chaves LJ (2005). Genetic structure of natural Eugenia dysenterica DC (Myrtaceae) populations in northeastern Goiás, Brazil, accessed by morphological traits and RAPD markers. Genet. Mol. Biol. 28: 407-413.

Vencovsky R and Crossa J (1999). Measures of Representativeness. In: Plant Breeding in the Turn of the Millennium (Borém A, Giúdice MP and Sakiyama NS, eds.). Universidade Federal de Viçosa, Viçosa, 335-354.

Vencovsky R, Nass LL, Cordeiro CMT and Ferreira MAJ (2007). Amostragem em Recursos Genéticos Vegetais. In: Recursos Genéticos Vegetais (Nass LL, ed.). Vol. 7. Embrapa Recursos Genéticos e Biotecnologia, Brasília, 231-280.

Williams JG, Kubelik AR, Livak KJ, Rafalski JA, et al. (1990). DNA polymorphisms amplified by arbitrary primers are useful as genetic markers. Nucleic Acids Res. 18: 6531-6535.

Wright S (1951). The genetical structure of populations. Ann. Eugenics 15: 323-354.

Yeh FC and Boyle TJB (1997). Population genetic analysis of co-dominant and dominant markers and quantitative traits. Belg. J. Bot. 129: 157. Popgene version 1.32. Available at [http://www.ualberta.ca/ fyeh/download.htm]. Accessed March 2007.

Yunes RA and Filho VC (2001). Plantas Medicinais sob a Ótica da Química Medicinal Moderna. Argos, Chapecó.

Zucchi MI, Pinheiro JB, Chaves LJ, Coelho ASG, et al. (2005). Genetic structure and gene flow of Eugenia dysenterica natural populations. Pesq. Agropec. Bras. 40: 975-980. 